\title{
CURRENT STATE OF THE EMPLOYEE PERFORMANCE APPRAISAL SYSTEM IN AGRICULTURAL ORGANIZATIONS IN THE CZECH REPUBLIC
}

\author{
Kateřina Venclová, Martina Königová, Jiří Fejfar \\ Received: February 28, 2013
}

\begin{abstract}
VENCLOVÁ KATEŘINA, KÖNIGOVÁ MARTINA, FEJFAR JIŘí: Current state of the employee performance appraisal system in agricultural organizations in the Czech Republic. Acta Universitatis Agriculturae et Silviculturae Mendelianae Brunensis, 2013, LXI, No. 4, pp. 1183-1189

Employee performance appraisal is one of the most important human resource management tools. The first part of the article concentrates on the theoretical background. The second part evaluates the results of the quantitative survey. The aim of the article is to evaluate the use of formal appraisal of employees in agricultural organizations in the Czech Republic and to test dependencies between selected qualitative characteristics. The results of the survey show that only $12.3 \%$ of agricultural organizations ( $\mathrm{n}=332$ ) use formal appraisal of employees. They also confirm that the application of the formal appraisal of employees in agricultural organizations depends on the size of the agricultural organization ( $p$-value 0.006, Phi coefficient 0.151 ) and the existence of a personnel department (p-value 0.000 , Phi coefficient 0.210 ). 49.1\% of agricultural organizations did not consider formal appraisal important. Only $5.8 \%$ of agricultural organizations that do not use any system of formal employee performance appraisal plan its implementation, despite the fact that currently people are considered to be the most important strategic asset of any organization for achieving a competitive advantage.
\end{abstract}

agriculture, agricultural organizations, employee performance appraisal, human resources, performance, survey

It is generally considered that people are an organization's most important asset. Alo (in Obisi, 2011) noted that an organization can only win a competitive advantage through people and therefore it is necessary to appraise them (Hroník, 2006; Koubek, 2007; Banfield, Kay, 2008; Bělohlávek, 2009; Plamínek, 2010).

Employee performance appraisal is one of the most important human resource management tools (Roberts, 2003; Dessler, 2011; Boachie-Mensah, Seidu, 2012). Human resource management has emerged as an important discipline that is used in many fields (Manoharan et al., 2012), e.g. for reward (Brown et al., 2010; Thurston, McNall, 2010) and career planning (Appelbaun et al., 2011). Performance appraisal is also an integral part of the process of human resources performance management (Brown et al., 2010; Palailogos et al., 2011; Lussier, Hendon, 2012; Snell, Bohlander, 2012). According to Brown et al. (2010) and Tuytens and Devos (2012) performance appraisal is designed to stimulate employee performance as well as organization performance (Appelbaun et al., 2011).

Moreover, performance appraisal is a formal organizational process carried out on systematic basis to provide comparison between individual (or group) performance expected and the performance provided (Coates in Giangreco et al., 2010). It is typically conducted as a formal, discrete event occurring annually or semi-annually to assist with administrative decisions (e.g. pay raises) and employee development (e.g. identifying training 
opportunities and areas for improvement) (Armstrong, 2009; Murphy, Cleveland in Spence, Keeping, 2012).

The 2 lst century is characterized by there being very little professional interest in work in agriculture. So research in the area of personnel management is focused on other areas (Bitsch, 2009), even though of the 19 sections of CZ-NACE (Classification of Economic Activities) the proportion of those working in agriculture, forestry and fishery is in 9th place with respect to the employment of people in NH (National Economy) Czech republic (Czech Statistical Office, 201la).

The aim of the article is therefore (1) to evaluate the use of formal appraisal of employees in agricultural organizations in the Czech Republic, based on analysis of survey data; (2) to identify the reasons for not having introduced a formal employee performance appraisal system in agricultural organizations in the Czech Republic and (3) to test dependencies between selected qualitative characteristics that relate to the issues examined. The article has been produced on the basis of an analysis of primary and secondary sources, in particular research studies focusing on employee performance appraisal. Primary data is derived from a questionnaire survey carried out to explore the application of employee performance appraisal in agricultural organizations in the Czech Republic.

\section{MATERIALS AND METHODS}

A quantitative survey was conducted from June 2012 to September 2012 focusing on the application of formal appraisal of employees in agricultural organizations in the Czech Republic. It was carried out by means of a questionnaire survey that contained 19 questions, six of which were qualitative in nature. The sample group consisted of 1,698 agricultural organizations. The questionnaire return rate was $19.6 \%$ (332), of which small organizations (with up to 50 employees) amounted to $73.8 \%$, medium-sized organizations (from 51 to up to 249 employees) accounted for $25.9 \%$ and large organizations (over 250 employees) represented $0.3 \%$ of the sample. The small proportion of large agricultural organizations is due to their low representation in the Czech Republic. For example, according to the Czech statistical office (2011b), in 2011 these organizations represented only 0.059\% of organizations in the Central Bohemian Region. It is not possible to determine the exact number of agricultural organizations with more than 250 employees, as the size of agricultural organizations is usually measured according to the area of agricultural land rather than the number of employees. 96.1\% of organizations were domestic organizations, 2.7\% were Czech organizations with foreign participation and $1.2 \%$ were foreign organizations. In terms of their legal basis, the most frequent types of organization were limited liability companies (35.8\%), followed by co-operatives $(26.8 \%)$ and joint- stock companies (22.9\%). The data obtained were processed by means of absolute and relative frequencies using the Microsoft Excel 2007 program and the IBM SPSS program. Testing was carried out using the Pearson Chi-Square test in contingency tables. To interpret the strength of relationship coefficients (the Phi coefficient, Cramer's coefficient and the Contingency coefficient), a scale according to de Vaus (2002) was used.

\section{RESULTS}

\section{A) Application of formal appraisal in agricultural organizations in the Czech Republic}

The survey conducted has shown that only $12.3 \%$ of agricultural organizations use formal employee appraisal. Formal employee performance appraisal means the regular assessment of employees by applying pre-defined performance appraisal methods. $87.7 \%$ of agricultural organizations do not

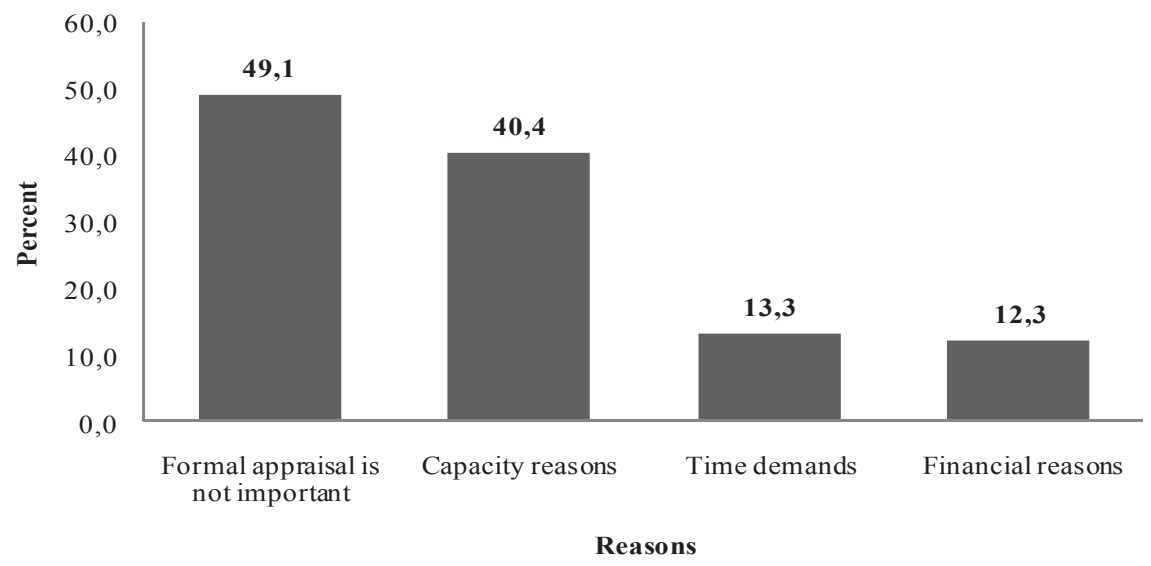

1: Reasons for the absence of formal employee performance appraisal in agricultural organizations in the Czech Republic

Source: Authors' survey 


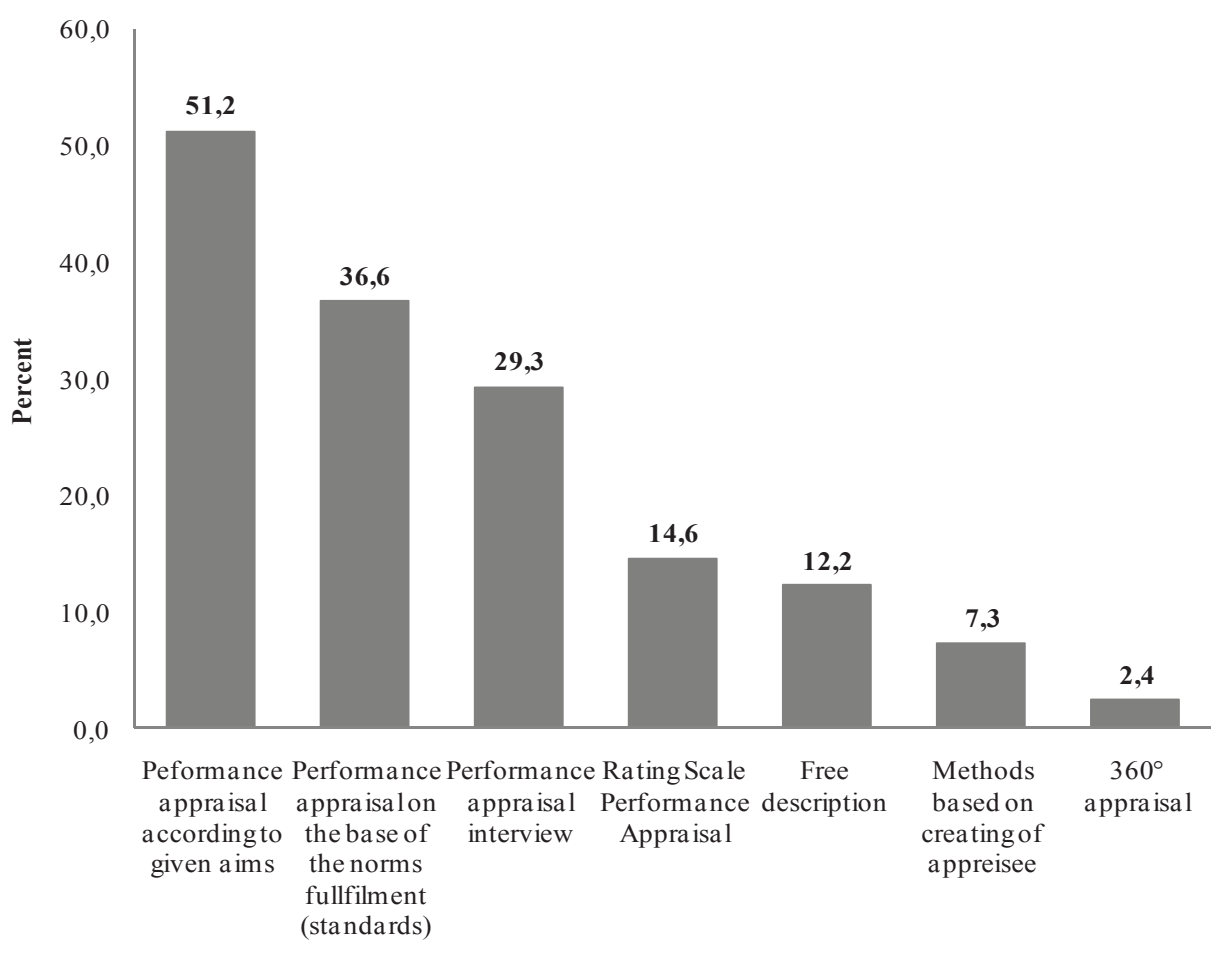

Performance appraisal methods

2: Performance appraisal methods used in agricultural organizations

Source: Authors' survey

use formal employee performance appraisal (73.8\% of which are small organizations with up to 50 employees) despite the fact that currently people are considered to be the most important strategic asset of any organization for achieving a competitive advantage. Among the reasons for not having introduced a formal employee performance appraisal system, one factor may be that only $13 \%$ of agricultural organizations have a personnel department within their corporate structure. In this survey $49.1 \%$ of agricultural organizations stated that they did not consider formal appraisal important, $40.4 \%$ mentioned capacity reasons $173.8 \%$ of which are medium-sized organizations i.e. from 51 to up to 249 employees), $12.3 \%$ indicated financial reasons, $13.3 \%$ time demands. The above results are illustrated in Fig. 1.

Agricultural organizations that apply formal employee appraisal may conduct appraisal on an annual basis (39\%), quarterly basis (26.8\%), monthly basis (17\%), continuously (9.8\%) or on a bi-yearly basis (7.3\%). Only $41.5 \%$ of organizations with a formal appraisal system have a written employee performance appraisal methodology within its stated policy. The most frequently used appraisal methods are: Performance appraisal according to given aims (51.2\%), Performance appraisal on the basis of norms fulfilment (standards) (36.6\%), Performance appraisal interview (29.3\%), Rating Scale Performance Appraisal (14.6\%), Free description (12.2\%), Methods based on creating of appreisee (7.3\%) and the 360-degree appraisal (2.4\%). These results are shown in Fig. 2.

To collect information for the appraisal of employees, agricultural organizations most frequently refer to the opinion of an employee's direct superior (92.7\%), a senior superior (39\%), the employee being appraised (24.4\%), customers (14.6\%), colleagues (9.8\%), or a subordinate (2.4\%). $65.8 \%$ of agricultural organizations that apply formal appraisal give employees an opportunity to comment on the results of their appraisal. In $29.3 \%$ of agricultural organizations the appraisal results are intended solely for appraisers, while $4.9 \%$ of agricultural organizations communicate the outcomes of the appraisal to their employees without letting the employees comment on them. All agricultural organizations using formal appraisal of employees store the results for further use. They are most commonly used in the Human Resource (HR) Management areas of reward allocation (92.7\%), HR planning (19.5\%), learning and development (17.1\%) and career development for progression up the corporate ladder (7.3\%). These results are shown in Fig. 3.

This survey has revealed that a majority of agricultural organizations in the Czech Republic do not use a formal system of employee performance appraisal. This is despite the fact that $82.9 \%$ organizations have confirmed that formal appraisal of employees determines their performance. $56.1 \%$ of these organizations have also confirmed that they saw an improvement in 


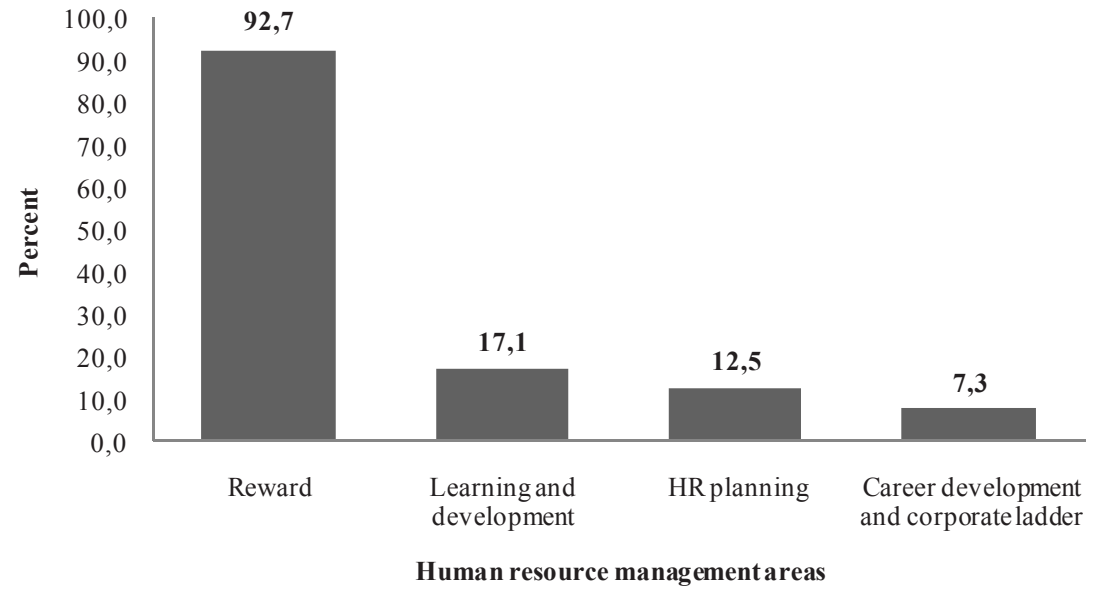

3: Utilization of performance appraisal data in human resource management areas Source: Authors' survey

productivity following the implementation of a formal employee performance appraisal system. Only 5.8\% of agricultural organizations that do not use any system of formal employee performance appraisal plan its implementation. $70.6 \%$ of these organizations plan to implement formal appraisal of employees within a three-year time horizon.

\section{B) Comparison of the application of the formal employee appraisal in small and medium-sized organizations}

The survey has revealed that only $9.4 \%$ of agricultural organizations with up to 50 employees have established a formal employee performance appraisal system established. As regards organizations with 51 up to 249 employees, formal appraisal is used by $20.7 \%$ of them. Since only one agricultural organization with more than 250 employees took part in the survey, it was necessary, for the purpose of statistical testing of the predefined hypothesis ( $\mathrm{Hl}$ ), to merge the groups of organizations to create only two groups - one with up to 50 employees and a second 51 and more employees. Using extracted data, dependency was tested by applying Pearson's Chi-Square Test $(\chi-$ square test). The SPSS programme employed uses the so-called p-value as an output in dependency testing. The p-value in hypothesis testing equals the minimum significance level at which the null hypothesis can be rejected. Should the calculated $\mathrm{p}$-value be lower than the set significance level of 0.05 , it is possible to say that the null hypothesis, i.e. the hypothesis on the independence of qualitative characteristics, is rejected at the 5\% level of significance. As the $p$-value calculated by means of the $\chi$-square test of 0.006 is lower than the selected level of significance $\alpha=0.05$, the null hypothesis has been rejected. The results of this test have confirmed that the application of formal employee performance appraisal is dependent on the size of the agricultural organizations (an alternative hypothesis to hypothesis No. 1). The strength of the relationship between the variables is, according to the value of Phi coefficient (0.151), Cramer's coefficient (0.151) and contingency coefficient (0.149), direct (with respect to the positive value) and low; see Tab. I.

\section{C) System of Personnel Management in Agricultural Organizations}

The system of personnel management in agricultural organizations is among the important factors that determine the application of formal employee performance appraisal in agricultural

I: The results of the qualitative characteristics test for hypotheses 1, 2 and 3

\begin{tabular}{|c|c|c|c|c|c|}
\hline $\begin{array}{l}\text { Number of } \\
\text { hypothesis }\end{array}$ & Null hypothesis $\left(\mathbf{H}_{0}\right)$ & P-value & $\begin{array}{c}\text { Rejection } \\
\text { of } \mathbf{H}_{0}\end{array}$ & $\begin{array}{c}\text { Value of Phi } \\
\text { coefficient }\end{array}$ & $\begin{array}{l}\text { Strength of the } \\
\text { relationship }\end{array}$ \\
\hline 1 & $\begin{array}{l}\text { The utilisation of the formal appraisal of employees } \\
\text { does not depend on the size of the agricultural } \\
\text { organization. }\end{array}$ & 0.006 & Yes & 0.151 & low \\
\hline 2 & $\begin{array}{l}\text { The utilisation of the formal appraisal of employees } \\
\text { in the agricultural organization does not depend on } \\
\text { the existence of a personnel department. }\end{array}$ & 0.000 & Yes & 0.210 & low \\
\hline 3 & $\begin{array}{l}\text { The existence of a personnel department in the } \\
\text { agricultural organization does not depend on the size } \\
\text { of the agricultural organization. }\end{array}$ & 0.000 & Yes & 0.362 & moderate \\
\hline
\end{tabular}

Source: Authors' survey 
organizations. The survey conducted has revealed that in agricultural organizations that do not have a personnel department, formal appraisal is used by only $9.7 \%$ of organizations. In those organizations whose corporate structure includes a personnel department, formal appraisal is used by $30.2 \%$ of them. Simultaneously it has been validated that the need for the establishment of a personnel department grows with the size of the company (i.e. according to the number of employees). Only $5.7 \%$ of agricultural organizations surveyed with less than 50 employees have a personnel department. In the category of 51 to 249 employees, 32.6\% of agricultural organizations have a personnel department and in agricultural organizations with more than 250 employees $100 \%$ of agricultural organizations have a personnel department. In 70.1\% of agricultural organizations personnelrelated activities are performed by only 1 employee.

Based on the above information, null hypothesis No. 2 was tested on the lack of dependence between the employee performance formal appraisal and the existence of a personnel department. Based on the $\chi$-square test, the null hypothesis was rejected at the $5 \%$ level of significance $(p$-value $=0.000)$. The strength of the relationship between the variables is, according to the value of Phi coefficient (0.210), Cramer's coefficient (0.210) and Contingency coefficient (0.205), direct (with respect to the positive value) and low; see Tab. I. Thus the utilization of formal employee performance appraisal in an organization depends on the existence of a personnel department.

This was followed by testing of null hypothesis no. 3 on the lack of dependence between the existence of a personnel department and the size of the agricultural organization. Based on the $\chi-$ square test, the null hypothesis was rejected at the $5 \%$ level of significance $(p$-value $=0.000)$. The strength of the relationship between the variables is, according to the value of Phi coefficient (0.362), Cramer's coefficient (0.362) and Contingency coefficient (0.340), direct (with respect to the positive value) and moderate; see Tab. I.

\section{DISCUSSION}

The significance of formal employee performance appraisal lies in the fact that its outcomes represent an important background for strategic personnel decisions. Employee performance appraisal should therefore form part of the recruitment process and should be involved in all other employee activities in the organization. The easiest time to begin the performance appraisal process is when an employee is hired. It then becomes an expected part of the job and is not something that the employee views as new and different or, perhaps, fears. This would be especially true on a farm where there has been a long-standing tradition of providing employees with little or no feedback about their performance (University of Vermont, 2012).
The results of the present survey show that $87.7 \%$ of agricultural organizations do not use formal employee performance appraisal $73.8 \%$ of which are small organizations with up to 50 employees), despite the fact that $82.9 \%$ of agricultural organizations that have an appraisal system in place confirm the impact of a formal system of employee appraisal system on employee performance. 56.1\% of agricultural organizations saw an improvement in employee performance after the introduction of a formal employee performance appraisal system. These results are confirmed also by Billikopf (2003) who also pointed out that performance improved substantially (from 11 to 27 percent) in a number of settings when employees were given specific goals to achieve and received performance feedback.

According to Bitsch (2009), one of the challenges faced by agricultural organizations in the 21st century is the attraction, motivation, and retention of sufficient and qualified labour. However, personnel management research has mostly focused on other industries. Accordingly, agricultural managers have little to rely on, when developing personnel policies and procedures. Once a business has grown beyond the labour capacity of the immediate family, personnel management becomes an issue and practices developed for large corporations do not always scale down well to smaller businesses or may not fit the agribusiness environment.

Billikopf (2003) states, that despite the importance of formal appraisals, an effective manager does not wait for formal performance appraisal interviews to communicate with employees. Sharing information about performance should be done frequently and in a positive manner. An effective negotiated performance appraisal helps the employee take additional ownership for both continuing effective performance and improving weak areas.

\section{CONCLUSION}

At present, there is a minor demand for agricultural jobs, in particular in industrial and developed economies and in growing and transition economies. Surveys in the area of human resource management are usually focused on other sectors. If agricultural organizations appraise their employees, they usually utilize informal employee performance appraisal. This is confirmed by the outcomes of the present survey. The results of the survey show that only $12.3 \%$ of agricultural organizations use formal employee performance appraisal. The results also confirm that the application of formal employee performance appraisal in an agricultural organization depends on the size of the agricultural organization and the existence of a personnel department. $49.1 \%$ of agricultural organizations did not consider formal appraisal important. Of particular interest is the fact that only $5.8 \%$ of agricultural organizations that do not use any formal employee performance appraisal system plan its implementation, despite the fact that currently 
people are considered to be the most important strategic asset of any organization for achieving a competitive advantage. Agricultural organizations should deal effectively with their employees because agriculture is an important sector of any economy. Moreover, it feeds the population and therefore carries a certain strategic importance (Van den Ban and Samanta in Karimi et al., 2011).

\section{SUMMARY}

Employee performance appraisal is one of the most important human resource management tools. The article focuses on issues of employee performance appraisal with emphasis on the use of formal employee performance appraisal in agricultural organizations in the Czech Republic. The aim of the article is to evaluate the use of formal employee appraisal in agricultural organizations in the Czech Republic and to test dependencies between selected qualitative characteristics. The article is organized as follows: the first part of the article concentrates on the theoretical background; the second part evaluates the results of the quantitative survey. The sample group consisted of 1,698 agricultural organizations. The questionnaire return rate was 19.6\% (332). The results of the survey show that only $12.3 \%$ of agricultural organizations use formal employee performance appraisal. Among the reasons for not having introduced a formal employee performance appraisal system, 49.1\% of agricultural organizations stated that they did not consider formal employee performance appraisal to be important, 40.4\% mentioned capacity reasons, $12.3 \%$ indicated financial reasons, $13.3 \%$ time demands. Agricultural organizations that apply formal employee appraisal conduct appraisal, in the majority of cases, on an annual basis (39\%), using Performance Appraisal according to given aims (51.2\%). To collect information for the employee performance appraisal, agricultural organizations most frequently refer to the opinion of an employee's direct superior (92.7\%). 65.8\% of the agricultural organizations that apply formal appraisal give employees the possibility to comment on the results of the performance appraisal. All agricultural organizations that use formal employee performance appraisal store the results for further use. They are most commonly used in the area of reward (92.7\%). The results of the survey confirm that the application of formal employee performance appraisal in agricultural organizations depends on the size of the agricultural organization (p-value 0.006, Phi coefficient 0.151) and the existence of a personnel department (p-value 0.000, Phi coefficient 0.210). 49.1\% of agricultural organizations did not consider formal employee appraisal important. Only 5.8\% of agricultural organizations that do not use any system of formal employee performance appraisal plan its implementation, despite the fact that currently people are considered to be the most important strategic asset of any business for achieving a competitive advantage.

\section{Acknowledgement}

This article is a research project of the Czech University of Life Sciences and has been made possible due to the support of the Internal Grant Agency (IGA) of the CULS Prague, Registration No. 20121036 - Employee performance appraisal as a performance management tool.

\section{REFERENCES}

APPELBAUM, S. H., ROY, M. GILLILAND, T., 2011: Globalization of performance appraisals: theory and applications. Manage Decis, 49, 4: 570-585. ISSN 0025-1747.

ARMSTRONG, M., 2009: Armstrong's handbook of human resource management practice. $11^{\text {th }}$ ed. Philadelphia: Kogan Page, 1062 p. ISBN 07-4945242-0.

BANFIELD, P., KAY, R., 2008: Introduction to human resource management. Ist ed. New York: Oxford University Press, 367 p. ISBN 978-0-19-929152-6.

BĚLOHLÁVEK, F., 2009: Jak vést rozhovory $s$ podrízenými pracovníky. $1^{\text {st }}$ ed. Prague: Grada Publishing, 136 p. ISBN 978-80-247-2313-6.

BITSCH, V., 2009: Personnel Management Research in Agribusiness. 19th Annual World Forum and Symposium of the International Food and Agribusiness Management Association, Budapest. Available online at: https://www.ifama.org/events/ conferences/2009/cmsdocs/1067_paper.pdf [cited 2. 1. 2013].

BOACHIE-MENSAH, F., SEIDU, P. A., 2012: Employees' Perception of Performance Appraisal System: A Case Study. International Journal of Business and Management, 7, 2: 73-88. ISSN 1833-8119.

BROWN, M., HYATT, D., BENSON, J., 2010: Consequences of the performance appraisal experience. Pers Rev, 39, 3: 375-396. ISSN 00483486.

CZECH STATISTICAL OFFICE, 201la: Zaměstnanost $v$ NH dle kraju. Available online at: www.czso. cz/csu/2012 edicniplan.nsf/t/EA0034DB14/ \$File/31151215.pdf [cited 3. 1. 2013].

CZECH STATISTICAL OFFICE, 201lb: Ekonomické subjekty ve Strédočeském kraji v roce 2011. Available online at: http://www.czso.cz/xs/redakce.nsf/bce4lad0daa3aadlc1256c6e00499152/3264ed87d5 
de747ec1257996004af96b/\$FILE/RES_2011.pdf [cited 3. 1.2013].

DE VAUS, D., 2002: Surveys in Social Research. $5^{\text {th }}$ ed. London: Routledge/Taylor and Francis, 379 p. ISBN 041-5268583.

DESSLER, G., 2011: Human Resource Management. $12^{\text {th }}$ ed. New Jersey: Pearson Education, 736 p. ISBN 978-8131754269.

GIANGRECO, A., CARUGATI, A., SEBASTIANO, A., TAMIMI, H. A., 2012: War outside, ceasefire inside: An analysis of the performance appraisal system of a public hospital in a zone of conflict. Eval Program Plann, 35, 1: 161-170. ISSN 0149-7189.

HRONÍK, F., 2006: Hodnocení pracovníku. $1^{\text {st }}$ ed. Prague: Grada Publishing, 128 p. ISBN 80-2471458-2.

KARIMI, A. MALEKMOHAMADI, I., DARYANI, M. A., REZVANFAR, A., 2011: A conceptual model of entrepreneurship in the Iranian agricultural extension organization: Implications for HRD. Journal of European Industrial Training, 35, 7: 632 657. ISSN 0309-0590.

KOUBEK, J., 2007 Personální práce v malých a středních firmách, 4 ${ }^{\text {th }}$ ed. Prague: Grada Publishing, 264 p. ISBN 978-80-247-2202-3.

LUSSIER, R. N., HENDON, J. R., 2012: Human Resource Management: Functions, Applications, Skill Development. $1^{\text {st }}$ ed. Los Angeles: SAGE Publications, 588 p. ISBN 9781412992428.

MANOHARAN, T. R., MURALIDHARAN, C. DESCHMUKH, S. G., 2012: A composite model for employees' performance appraisal and improvement. European Journal of Training and Development, 36, 4: 448-480. ISSN 2046-9012.

OBISI, CH., 2011: Employee performance appraisal and its implication for individual and organizational growth. Australian Journal of Business and Management Research, 1, 9: 92-97. ISSN 18390846.

PALAIOLOGOS, A., PAPAZEKOS, P., PANAYOTOPOULOU, L. 2011: Organizational justice and employee satisfaction in performance appraisal. Journal of European Industrial Training, 35, 8: 826840. ISSN 0309-0590.

PLAMÍNEK, J., 2009: Týmová spolupráce a hodnocení lidí. $1^{\text {st }}$ ed. Prague: Grada Publishing, 128 p. ISBN 978-80-247-2796-7.

ROBERTS, G. E., 2003: Employee Performance Appraisal System Participation: A Technique that Works. Public Pers Manage, 32, 1: 89-97. ISSN 00910260.

SNELL, S., BOHLANDER, G., 2012: Managing Human Resources. 16 ${ }^{\text {th }}$ ed. Manson: CENGAGE Learning, 793 p. ISBN 978-1-111-53282-6.

SPENCE, J. R., KEEPING, L. M., 2011: Conscious rating distortion in performance appraisal: A review, commentary, and proposed framework for research. Hum Resour Manage R, 21, 2: 85-95. ISSN 1053-4822.

THURSTON, P.W., McNALL, L., 2010: Justice perceptions of performance appraisal practices. Journal of Managerial Psychology, 25, 3: 201-228. ISSN 0268-3946.

TUYTENS, M., DEVOS, G., 2012: Importance of system and leadership in performance appraisal. Pers Rev, 41, 6: 756-776. ISSN 0048-3486.

UNIVERSITY OF VERMONT, 2012: Performance Appraisal. Available online at: http://www.uvm. edu/ farmlabr/?Page=personnel/evaluation . html\&SM=personnel/submenu_personnel.html [cited 11. 1.2013]. 